\title{
Aneurysmal bone cyst in the cervical spine
}

\author{
Nithish Jayakumar (10 , ${ }^{1}$ Habib Mohamed Bin Ismail, ${ }^{2}$ Sanjay Mulay, ${ }_{1}^{1}$ Neil Ashwood ${ }^{1}$
}

'Department of Trauma \& Orthopaedics, University Hospitals of Derby and Burton NHS Foundation Trust, Burton upon Trent, UK

${ }^{2}$ Department of Radiology, University Hospital Coventry, Coventry, UK

\section{Correspondence to}

Nithish Jayakumar; nithish.jayakumar90@gmail. com

Accepted 25 September 2019

\section{DESCRIPTION}

A 7-year-old girl presented to the emergency department with 'clicking' in her neck while trampolining, on a background history of neck pain for a year. There was no obvious history of trauma. Examination of the neck demonstrated a firm mass posteriorly with preserved neck movements and absence of any neurological deficit. In view of her atypical history and clinical examination, plain X-rays were performed which revealed lytic lesions in the body of C2. Detailed imaging was undertaken through CT and MRI. On T2-weighted MRI (figure 1), a giant dumbbell-shaped, multiseptated bony lesion involving the body, laminae, and posterior elements of C2 were noted. Multiple fluid-fluid levels were present within the lesion, resembling a giant 'soap bubble'. CT images (figure 2) demonstrate the markedly enlarged bony lesion involving C2 with egg-shell thin cortices and increased vascular markings. Appearances were consistent with an aneurysmal bone cyst $(\mathrm{ABC})$ at the $\mathrm{C} 2$ level. The child was transferred to the regional paediatric spinal centre where a CT-guided biopsy confirmed ABC and she subsequently underwent curettage of the lesion with autologous bone grafting for spinal stabilisation.

$\mathrm{ABC}$ s are rare but benign, highly vascular tumours and account for up to $1 \%$ of all bone tumours and $15 \%$ of primary spinal tumours. ${ }^{1-4}$ The majority of $\mathrm{ABCs}$ occur in the first two decades of life $\mathrm{fe}^{1-4}$ and uncommonly affect the cervical spine, with only 71 cases reported in the literature till recently. ${ }^{1}$

Imaging features of $\mathrm{ABCs}$ are characteristic and remain key to diagnosis. Plain X-rays may show expansile, well-circumscribed lytic lesions with periosteal calcification ('eggshell-like') and cortical thinning, often described as a 'soap bubble' appearance. ${ }^{5-7}$ In this case, the MRI findings were also suggestive of a 'soap bubble' appearance (figure 1). The typical MRI findings include the presence of

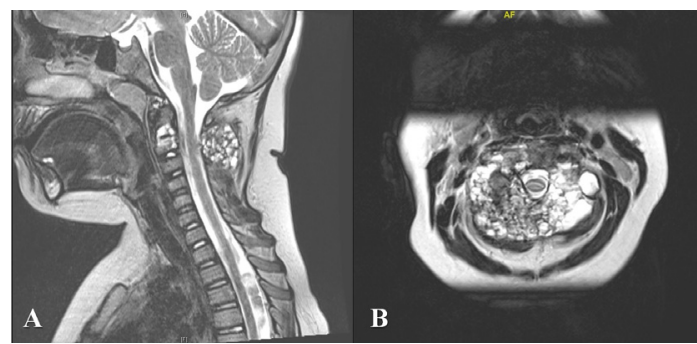

Figure 1 (A) Midsagittal T2-weighted MRI image demonstrating the extent of the loculated aneurysmal bone cyst $(A B C)$ at $C 2$ without any compression of the neural structures. (B) Axial T2-weighted MRI image demonstrating the multiseptated $A B C$ with fluid-fluid levels with complete involvement of $\mathrm{C} 2$.

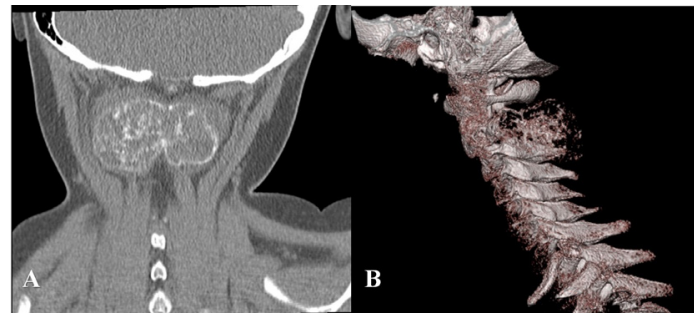

Figure 2 (A) Coronal view of non-contrast CT cervical spine demonstrating the dumbbell-shaped aneurysmal bone cyst of C2 with cortical thinning. (B) Sagittal three-dimensional reconstruction of the cervical spine demonstrating the lytic lesion at C2 associated with increasing vascular markings.

a multiseptated cystic lesion with fluid-fluid levels, hypointense on T1-weighted but hyperintense on T2-weighted images, and contrast-enhancing septal walls. ${ }^{3-9}$ Fluid-fluid levels, in particular, are strongly suggestive of an ABC. ${ }^{10}$ However, a plethora of other diseases including giant cell tumour, eosinophilic granuloma, fibrous dysplasia, unicameral bone cyst, chondroblastoma, chondrosarcoma, chondromyxoid fibroma, Ewing's tumour and metastatic carcinoma have all been reported to display similar imaging features as an ABC. ${ }^{145} \mathrm{~A}$ combination of both radiographs and MRI, alongside histological examination, is required to increase the likelihood of an accurate diagnosis. ${ }^{5}$

Although complete surgical excision of ABCs has been associated with high rates of cure, ${ }^{11} 12$ recurrence, however, remains a concern even after complete excision. ${ }^{1-4781113}$ The risks of aggressive surgery include spinal instability which may necessitate spinal instrumentation and fusion. ${ }^{23}$ Perioperative embolisation to aid vascular control has

\section{Learning points}

- Aneurysmal bone cysts (ABCs) of the spine are benign, vascular tumours and account for up to $15 \%$ of primary spinal tumours. It is important to investigate thoroughly in cases with atypical presentations, as in this report.

- Radiological features of ABCs include lytic lesions with periosteal calcification, often described as a 'soap bubble' appearance. MRI findings include a multiseptated lesion with fluid-fluid levels, hyperintense on $\mathrm{T} 2$ and hypointense on T1-weighted imaging.

- Combination of both radiographic and MRI features help clinch the diagnosis although histological examination is often warranted to exclude other, more sinister, lesions. 
also been used as adjuvant therapy. ${ }^{11}$ Less aggressive surgical options include curettage ${ }^{14}$ while sclerotherapy is also reported to be safe and effective. ${ }^{11}$

In conclusion, we present the striking images of a giant 'soap bubble' representing an $\mathrm{ABC}$ in the cervical spine of a 7-year-old girl. Surgical management was successfully undertaken, and the patient is well at 5-year follow-up.

Contributors NJ and $\mathrm{HMBI}$ wrote the initial manuscript and created the figures. SM was in charge of the patient's clinical care and provided critical comments on the draft. NA was the overall supervisor and helped write the final draft. All authors contributed equally to the project and agree to grant the rights to the BMJ.

Funding The authors have not declared a specific grant for this research from any funding agency in the public, commercial or not-for-profit sectors.

Competing interests None declared.

Patient consent for publication Parental/guardian consent obtained.

Provenance and peer review Not commissioned; externally peer reviewed.

\section{ORCID iD}

Nithish Jayakumar http://orcid.org/0000-0002-2321-2204

\section{REFERENCES}

1 Protas M, Jones LW, Sardi JP, et al. Cervical spine aneurysmal bone cysts in the pediatric population: a systematic review of the literature. Pediatr Neurosurg 2017:52:219-24.
2 Novais EN, Rose PS, Yaszemski MJ, et al. Aneurysmal bone cyst of the cervical spine in children. J Bone Joint Surg Am 2011;93:1534-43.

3 Sebaaly A, Ghostine B, Kreichati G, et al. Aneurysmal bone cyst of the cervical spine in children: a review and a focus on available treatment options. J Pediatr Orthop 2015;35:693-702.

4 Mankin HJ, Hornicek FJ, Ortiz-Cruz E, et al. Aneurysmal bone cyst: a review of 150 patients. J Clin Oncol 2005;23:6756-62.

5 Mahnken AH, Nolte-Ernsting CCA, Wildberger JE, et al. Aneurysmal bone cyst: value of Mr imaging and conventional radiography. Eur Radio/ 2003;13:1118-24.

6 Kuna S, Gudena R. "Soap bubble" in the calcaneus. CMAJ 2011:183:1171.

7 Pennekamp W, Peters S, Schinkel C, et al. Aneurysmal bone cyst of the cervical spine (2008:7b). Eur Radiol 2008;18:2356-60.

8 Boubbou M, Atarraf K, Chater L, et al. Aneurysmal bone cyst primary--about eight pediatric cases: radiological aspects and review of the literature. Pan Afr Med J 2013;15.

9 Beltran J, Simon DC, Levy M, et al. Aneurysmal bone cysts: MR imaging at 1.5 T. Radiology 1986;158:689-90.

10 Davies AM, Cassar-Pullicino VN, Grimer RJ. The incidence and significance of fluid-fluid levels on computed tomography of osseous lesions. Br J Radiol 1992;65:193-8.

11 Tsagozis P, Brosjö 0. Current strategies for the treatment of aneurysmal bone cysts. Orthop Rev 2015;7:6182.

12 Liu JK, Brockmeyer DL, Dailey AT, et al. Surgical management of aneurysmal bone cysts of the spine. Neurosurg Focus 2003;15:1-7.

13 Frassanito P, D'Onofrio GF, Pennisi G, et al. Multimodal management of aggressive recurrent aneurysmal bone cyst of spine: case report and review of literature. World Neurosurg 2019;126:423-7.

14 Reddy KIA, Sinnaeve F, Gaston CL, et al. Aneurysmal bone cysts: do simple treatments work? Clin Orthop Relat Res 2014;472:1901-10.

Copyright 2019 BMJ Publishing Group. All rights reserved. For permission to reuse any of this content visit

https://www.bmj.com/company/products-services/rights-and-licensing/permissions/

BMJ Case Report Fellows may re-use this article for personal use and teaching without any further permission.

Become a Fellow of BMJ Case Reports today and you can:

- Submit as many cases as you like

- Enjoy fast sympathetic peer review and rapid publication of accepted articles

- Access all the published articles

Re-use any of the published material for personal use and teaching without further permission

Customer Service

If you have any further queries about your subscription, please contact our customer services team on +44 (0) 2071111105 or via email at support@bmj.com.

Visit casereports.bmj.com for more articles like this and to become a Fellow 